\title{
A new record of kelp Lessonia spicata (Suhr) Santelices in the Sub-Antarctic Channels: implications for the conservation of the "huiro negro" in the Chilean coast
}

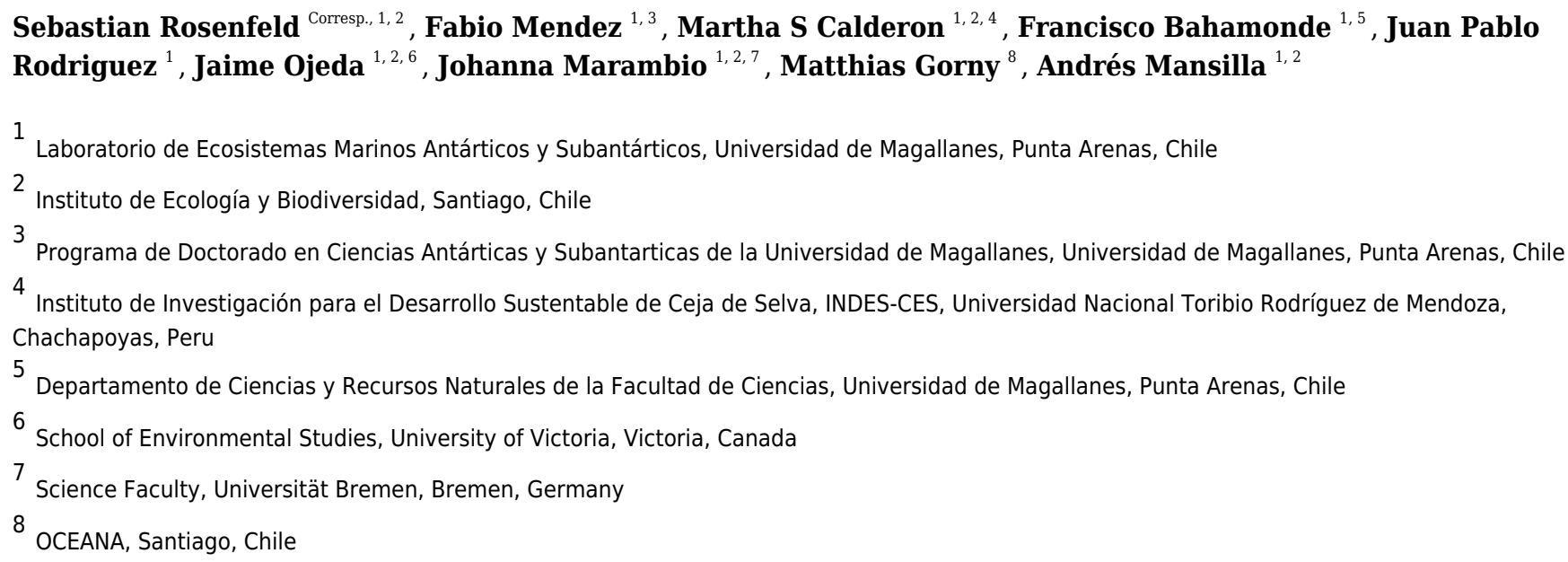

The Katalalixar National Reserve (KNR) lies in an isolated marine protected area of Magellan Sub-Antarctic channels, which represent an important area for marine biodiversity and macroalgal conservation. The present study is the first report of the species Lessonia spicata, "huiro negro", in the Magellan Sub-Antarctic channels. This finding has implications for macroalgal biogeography and conservation concerns in the Chilean coast. In the ecological assessments of the KNR in 2018 we found populations of $L$. spicata, specifically on rocky shores of Torpedo Island and Castillo Channel. The morphological identification and molecular phylogeny based on nuclear (ITS1) sequences revealed that these populations of Lessonia are within the lineage of $L$. spicata of central Chile. This report increases the species richness of kelps for the Magellan Sub-Antarctic Channels from 2 to 3 confirmed species (L. flavicans, L. searlesiana and L. spicata), and it also extends the southern distribution range of $L$. spicata. This species has high harvest demand which is moving towards southern Chile, thus these populations should be considered as essential for macroalgal conservation in high latitudes of South America. 


\author{
A new record of kelp Lessonia spicata (Suhr) Santelices in the Sub-Antarctic Channels: \\ implications for the conservation of the "huiro negro" in the Chilean coast \\ Sebastián Rosenfeld ${ }^{1,2}$, Fabio Méndez ${ }^{1,3}$, Martha S. Calderon ${ }^{1,2,4}$, Francisco Bahamonde ${ }^{1,5}$, Juan Pablo \\ Rodríguez $^{1}$, Jaime Ojeda ${ }^{2,6}$, Johanna Marambio ${ }^{2,7}$, Matthias Gorny ${ }^{8}$ and Andrés Mansilla ${ }^{1,2}$ \\ ${ }^{1}$ Laboratorio de Ecosistemas Marinos Antárticos y Subantárticas (LEMAS), Universidad de \\ Magallanes, Punta Arenas, Chile. \\ ${ }^{2}$ Instituto de Ecología y Biodiversidad (IEB), Santiago, Chile. \\ ${ }^{3}$ Programa de Doctorado en Ciencias Antárticas y Subantarticas de la Universidad de \\ Magallanes, Punta Arenas, Chile. \\ ${ }^{4}$ Instituto de Investigación para el Desarrollo Sustentable de Ceja de Selva, INDES-CES, \\ Universidad Nacional Toribio Rodríguez de Mendoza, Chachapoyas, Perú. \\ 14 5epartamento de Ciencias y Recursos Naturales de la Facultad de Ciencias, Universidad de \\ 15 Magallanes, Punta Arenas, Chile. \\ $16{ }^{6}$ School of Environmental Studies, University of Victoria, Victoria, British Columbia, Canada. \\ $17{ }^{7}$ Science Faculty, University of Bremen, Bremen, Germany \\ $18{ }^{8}$ Oceana Chile \\ 20 Corresponding Author: \\ 21 Sebastián Rosenfeld ${ }^{1}$ \\ 22 Laboratorio de Ecosistemas Marinos Antárticos y Subantárticas (LEMAS), Universidad de \\ Magallanes, Punta Arenas, Chile. Email address: sebastian.rosenfeld@umag.cl
}

\title{
Abstract
}

The Katalalixar National Reserve (KNR) lies in an isolated marine protected area of Magellan Sub-Antarctic channels, which represent an important area for marine biodiversity and macroalgal conservation. The present study is the first report of the species Lessonia spicata, "huiro negro", in the Magellan Sub-Antarctic channels. This finding has implications for macroalgal biogeography and conservation concerns in the Chilean coast. In the ecological assessments of the KNR in 2018 we found populations of L. spicata, specifically on rocky shores of Torpedo Island and Castillo Channel. The morphological identification and molecular phylogeny based on nuclear (ITS1) sequences revealed that these populations of Lessonia are within the lineage of L. spicata of central Chile. This report increases the species richness of kelps for the Magellan Sub-Antarctic Channels from 2 to 3 confirmed species (L. flavicans, L. searlesiana and L. spicata), and it also extends the southern distribution range of $L$. spicata. This species has high harvest demand which macroalgal conservation in high latitudes of South America. 
40

41

42

43

44

45

46

47

48

49

50

51

52

53

54

55

56

57

58

59

60

61

62

63

64

65

66

67

68

69

70

71

72

Key words: biogeography, conservation, extension, kelp, Magellan, Sub-Antarctic

\section{Introduction}

Lessonia Bory (Laminariales, Phaeophyceae) is one of the most conspicuous brown macroalgal genera that inhabit the littoral to sublittoral zone of rocky coasts ( $\sim 20 \mathrm{~m}$ depth) in temperate-cool waters of the South Pacific Ocean (Cho et al., 2006; Martin \& Zuccarello, 2012). There are currently records of 11 species of the genus Lessonia that are taxonomically accepted, distributed along the coasts of South America, New Zealand, Tasmania, and Sub-Antarctic islands (Cho et al., 2006). These species have major ecological roles in the structure of benthic marine communities (Villouta \& Santelices, 1984; Vásquez \& Santelices, 1984), and are commercially exploited for the extraction of alginic acid (Steneck et al., 2002). Lessonia species are one of the most characteristic and abundant macroalgae $\left(12^{\circ} \mathrm{S}\right.$ to $\left.56^{\circ} \mathrm{S}\right)$ that inhabit the rocky shores of the Chilean coast $\left(17^{\circ}\right.$ to $\left.56^{\circ} \mathrm{S}\right)$ (Searles, 1978; Avila et al., 1985; Villouta \& Santelices, 1986; Vasquez et al., 1998; Tellier et al., 2011; Martin \& Zucarello, 2012; Mansilla et al., 2014). Currently, six species have been recorded in Chile: Lessonia nigrescens Bory, Lessonia berteroana Montagne, Lessonia. spicata Suhr, Lessonia trabeculata Villouta \& Santelices, Lessonia searlesiana Asensi \& De Reviers and Lessonia flavicans Bory (Guiry \& Guiry, 2018). A recent morphological and molecular analysis showed that the species distributed from Peru (17 $)$ to Puerto Montt $\left(41^{\circ}\right)$, commonly known as L. nigrescens, is actually two cryptic species; the populations distributed from Peru $\left(17^{\circ} \mathrm{S}\right)$ to central Chile $\left(30^{\circ} \mathrm{S}\right)$ correspond to L. berteroana Montagne, and those occurring from central Chile $\left(29^{\circ} \mathrm{S}\right)$ to Puerto Montt $\left(41^{\circ} \mathrm{S}\right)$ correspond to $L$. spicata (Suhr) Santelices (González et al., 2012; Vega, 2016). However, L. nigrescens is still a valid species, because no material of the referred species has been found near its type locality, Cape Horn.

The huiro negro kelps, which include L. berteroana and L. spicata, are heavily exploited and represent almost 70\% of the kelp biomass landed annually (Vega et al., 2014). This economic activity is mainly practiced in northern Chile $\left(18-32^{\circ} \mathrm{S}\right)$, through a complex productive chain with high social impact and low added value (Vásquez, 2008). L. berteroana and L. spicata are exported as a natural commodity to more than 20 countries mainly due to their alginate, which has high economic value (Westermeier et al., 2019). Thus populations of huiro negro have economic interest along Chilean coasts, being essential to generate a stewardship from a local and large scale.

Peer) reviewing PDF | (2019:06:38495:1:1:REVIEW 25 Jul 2019) 
The Katalalixar National Reserve (KNR) is a national reserve area created in 1983. KNR comprises 674,500 ha and is located in a remote zone next to the village of Tortel. This area includes a wilderness temperate rainforest with a complex ecosystem of islands and fjords (Bell et al., 2007). The offshore area (western side) of the Magellan Sub-Antarctic Channels is one of the few places of the Magellan Biogeographic Province (MBP) ( $43^{\circ}-56^{\circ} \mathrm{S}$; Camus, 2001) that has not been explored systematically by scientific expeditions (Gorny \& Zapata, 2018) (Fig. 1a, b). KNR is located at the southern limit of the Humboldt Current System (HCS). The HCS is a key component of the general oceanic circulation in the eastern South Pacific, being one of the most productive marine ecosystems on the earth (Thiel et al., 2007). HCS is originated in southern Chile between $42-48^{\circ} \mathrm{S}$ and is characterized by a northward flow in front of South American coasts with a strong upwelling of cool nutrient-rich waters (Silva et al., 2009). The origin of the HCS induced a large-scale redistribution of biota, and nowadays plays a key role in the biogeography of the South Pacific (Camus, 2001). Thus KNR provides an enormous opportunity to understand the taxonomic composition and biogeography of macroalgae that inhabit the southern boundary of the Humboldt Current (Camus, 2001; Thiel et al., 2007).

The present study contributes the first report of the species L. spicata in the Magellan SubAntarctic Channels. The distribution of this was thought to be limited to $41^{\circ} \mathrm{S}$, but appears to be extended south of the Golfo de Penas ( $\left.46^{\circ} 59^{\prime}-47^{\circ} 40^{\prime} \mathrm{S}\right)$. Continuing survey studies will be necessary to understand the occurrence patterns of populations of $L$. spicata in the MBP.

\section{Materials \& Methods}

Three individuals of Lessonia spicata were collected in the intertidal zone of Torpedo Island and Castillo Channel (Fig. 1a, b) in July, 2018. The specimens were air-dried and then pressed on herbarium sheets for morphological observation and molecular analysis. The Chilean Hydrographic and Oceanographic Service of the Navy $\left(\mathrm{N}^{\circ}\right.$ 13270/24/337), approved field sampling.

External and internal morphological observations were made. The anatomical observations were performed by sectioning with a razor and staining with $1 \%$ aqueous aniline blue acidified with $1 \%$ diluted $\mathrm{HCl}$, and mounted in $70 \%$ glycerin. Photomicrographs were taken with a Canon Powershot S5 IS camera attached to a BX 51 Olympus microscope (Canon USA, Melville, New York, USA; Olympus Corp., Tokyo, Japan, respectively). A total of 15 replicates from the three 
104 individuals were selected for measurement of cortical cell diameter following Gonzalez et al.,

105 (2012); means and standard deviations were calculated. Samples of other species occurring in the

106 Sub-Antarctic region (L. flavicans and L. searlesiana) were also analyzed for comparative

107 purposes. Voucher specimens were deposited in the herbarium of University of Magallanes, Punta 108 Arenas, Chile.

109

\section{Molecular analyses}

111 Genomic DNA was extracted from $\sim 5 \mathrm{mg}$ of dried thallus ground in liquid nitrogen using a

112 NucleoSpin Plant II Kit (Macherey-Nagel, Düren, Germany) according to the manufacturer's

113 protocol. The PCR primers for the ITS were ITSP1-ITSRi (Tai et al., 2001; Martin \& Zucarello,

114 2012) and KP5- KG4 (Lane at al., 2006). Polymerase chain reaction products were purified using

115 a NucleoSpin Gel and PCR Clean-up (Macherey-Nagel, Düren, Germany) and commercially

116 sequenced (Macrogen, Seoul, South Korea). The electropherograms were edited using the

117 Chromas v1.45 software (McCarthy, 1998) and the new generated sequences were deposited in

118 GenBank (www.ncbi.nlm.nih.gov/genbank/).

119 A total of 34 ITS sequences (731bp) were included in the construction of the phylogeny: 31 120 sequences belonging to the genus Lessonia and three outgroups, Cymathaere triplicata (Postels \&

121 Ruprecht) J. Agardh, Ecklonia cava Kjellman and Macrocystis pyrifera (Linnaeus) C. Agardh

122 (Table 1). Sequences were aligned using the MUSCLE algorithm in MEGA5 v.6.06 software using 123 the default settings (Tamura et al., 2013).

124 The phylogenic analysis was constructed using Maximum likelihood (ML) and Bayesian inference 125 (BI) analyses. The program PartitionFinder (Lanfear et al., 2012) were used to choose the best126 fitting nucleotide substitution model under the Bayesian Information Criterion. The general time 127 reversible nucleotide substitution model with a gamma distribution and a proportion of invariable 128 sites $(\mathrm{GTR}+\Gamma+\mathrm{I})$ was selected as the best substitution model. ML analysis was performed with 129 the RAxML HPC-AVX program (Stamatakis, 2014) implemented in the raxmlGUI 1.3.1 interface 130 (Silvestro \& Michalak, 2012) with the statistical support obtained by 1000 bootstrap replications.

131 BI was performed with the MrBayes v. 3.2.5 software (Ronquist et al., 2012) using Metropolis132 coupled Markov Chain Monte Carlo $\left(\mathrm{MC}^{3}\right)$. The inference of Bayesian posterior probability (BPP) 133 was inferred following Calderon \& Boo (2017). 
134 The neighbor joining analysis was performed in MEGA5 v.6.06 with the default settings software, 135 using 1000 bootstrap replicates.

136

\section{Results}

138 This is the first confirmed report of L. spicata in the Sub-Antarctic region, extending its 139 distribution to the south by seven degrees of latitude (Fig. 2a). The sporophytes collected in the 140 two localities have cylindrical stipes, flattened toward the beginning of the blades, with a regular, 141 almost dichotomous long lanceolate blade with a spike (Fig. 2b-e).

\section{Internal anatomy}

144 Our specimens showed several layers of cortical tissue with cells of smaller diameter compared to 145 L. searlesiana (Fig. 3b, e, h) and L. flavicans (Fig. 3c, f, i), moreover no lacunas were observed in 146 our samples, unlike L. flavicans (Fig. 3c, h). The medulla was composed of elongated medullary 147 cells with filamentous elements (Fig. 3g). The internal anatomy was composed of a narrow cortex 148 (Fig. 3a), with cortical cell diameter of $25.91 \pm 2.90$ for the individual 1, 28.22 \pm 2.10 for individual 1492 , and $27.02 \pm 2.27$ for the individual 3 (Table 2).

\section{Phylogenetic analysis}

152 The ITS phylogeny placed our specimens within the lineage of L. spicata of central Chile (Fig. 153 4a). The phylogenetic trees constructed by ML and BI had the same topology except for the 154 phylogenetic position of $L$. corrugata and L. variegata from northeastern South Is. The three 155 specimens analyzed consistently formed a strongly supported clade with sequences of L. spicata 156 (97\% for ML and 0.96 for BPP) collected in Chile; having to L. berteroana and L. trabeculata as 157 sister taxa. The cladogram was consistent with the phylogenetic tree (Fig 4b). Variable sites 158 occurred at 201 positions (27.5\%), and 123 positions (16.8\%) were parsimoniously 159 informative. Intraspecific divergence of L. spicata from three different populations ranged 160 between $0.0 \%$ and $0.2 \%(0-3 \mathrm{bp})$. L. spicata differed by $0.8 \%-1.0 \%$ from L. berteroana and by $1611.1 \%-1.3 \%$ from L. trabeculata. L. variegata is a non-monophyletic species complex of four 162 different species.

163

\section{Discussion}


165 We confirm here the presence of L. spicata both morphologically and genetically, whose 166 individuals correspond to the central Chile lineage described by González et al., (2012). 167 Morphologically these features correspond to those described for L. spicata by Suhr (1839) and 168 González et al., (2012). These values also agree with those mentioned by González et al., (2012) 169 for L spicata. Genetically our phylogeny is consistent with those of previous studies that show Lessonia as a monophyletic lineage (Lane et al., 2006, Martin \& Zucarello, 2012).

Lessonia species are a characteristic component of benthic ecosystems in this region 172 (Searles, 1978; Martin \& Zucarello, 2011). We highlight two aspects about the importance of this 173 report of L. spicata for this area: a) we increase the knowledge of the species richness of kelps for 174 the Sub-Antarctic Channels, and (b) this species has a strong extraction activity which we 175 hypothesize that will move southward in the near future, therefore these populations should be properly preserved in order to prevent high risk of human impact.

177 The name L. spicata was proposed because it was the oldest name available to assign the lineage 178 of central Chile, populations between $29^{\circ}$ and $43^{\circ}$ S. However, L. spicata would be a provisional name mainly because no representative specimens of $L$. nigrescens have been found near the type locality Cape Horn. Therefore, if the true L. nigrescens belongs to one of the lineages already described or to a new one, this name would have priority (González et al., 2012). In the MBP $L$. nigrescens has been recorded not only for Cape Horn; Searles (1978) reported a population in the Trinidad Channel (Puerto Alert 49 53.6 'S), and two others in the Aysén region (Searles, 1978). Puerto Alert is $126 \mathrm{~km}$ south of Castillo Channel where we found the population of L. spicata. Therefore, it is likely that Searles' records (1978) correspond to populations of L. spicata. Finally, it is important to mention that, like González et al., (2012), in recent expeditions to the Diego Ramirez and Cape Horn archipelago-which are related to the characterization of the Diego Ramírez-Drake Passage Marine Park (Rozzi et al., 2017)-we have not found populations of $L$. nigrescens, only individuals of L. flavicans (Rozzi et al., 2017). Therefore, in the absence of

190 biological material from the type locality the status of L. nigrescens is still in doubt, and the lineage of central Chile that now extends south of $43^{\circ} \mathrm{S}$ should continue to be named as L. spicata.

192 Several bio-geographical breaks have been described along the coast of Chile (Santelices \& 193 Menesses, 2000; Tellier et al., 2009; Fraser et al., 2010); one of the most relevant for many taxa 194 is at $42^{\circ} \mathrm{S}$ (Brattström \& Johansen, 1983; Lancellotti \& Vázquez, 1999; Valdovinos et al., 2003). 195 For macroalgae and particularly for kelp species such as Durvillaea antarctica, a marked 
196 divergence is present south of $43^{\circ} \mathrm{S}$, where populations between $49^{\circ}$ and $55^{\circ} \mathrm{S}$ are genetically 197 different from the rest of the populations occurring in the Chilean coast $\left(32^{\circ} \mathrm{S}\right.$ and $\left.43^{\circ} \mathrm{S}\right)$ (Fraser 198 et al., 2010). These authors suggested that although D. Antarctica has a high dispersion capacity 199 due to its buoyancy (rafting), it could only colonize free coasts, since it would have limited 200 potential to increase gene flow between established populations. Therefore, it is interesting that 201 although L. spicata has a lowdispersal capacity in comparison to D. antarctica (Oppliger et al., 202 2012), since it does not have the buoyancy capacity, there is a single genetic unit in the individuals 203 collected in this study and individuals from the central zone of Chile. L. spicata must have some 204 physiological adaptations which allowed it to colonize and inhabit areas of high latitudes. In this 205 sense, this species has been described as a perennial seaweed and has not been found in the "bank of microscopic forms" in the Chilean central coast (boulders and water from tidal pools) (Santelices et al., 1995; Santelices et al., 2002). However, it has been observed that microscopic form of L. spicata can survive up to 90 days in total darkness and propagules can germinate in total absence of light (Santelices et al., 2002). This high capacity for tolerance to darkness could be a key strategy to colonize new areas with a significant seasonal changes in daylight hours and

211 luminosity (Photosynthetically Active Radiation) during the winter period (Ojeda et al., 2019).

212 Nevertheless, future studies and a greater number of samples along the Chilean coast (mainly the 213 area between $41^{\circ}-48^{\circ} \mathrm{S}$ ) will help to elucidate its biogeographic history and how much structure 214 and connectivity the populations of L. spicata present throughout their distribution $\left(29^{\circ} \mathrm{S}\right.$ to $\left.48^{\circ} \mathrm{S}\right)$.

215 The harvesting pressure on the genus Lessonia has increased alarmingly along the Chilean 216 coast, so we should take a precautionary approach to potential harvesting of $L$. spicata in its austral 217 distribution range. L. berteroana (sister species of L. spicata) is currently the most exploited 218 seaweed in South America; the main landings are in northern Chile (Westermeier et al., 2019). 219 Lessonia is socially important in this region because many artisanal fishers depend directly or 220 indirectly on its harvest (Vega et al., 2014). However, high demand, lack of oversight and harvest 221 methods have created a concerning scenario for kelp forests (Vega et al., 2014; Westermeier et al., 222 2019). The extraction of L. spicata in southern Chile began in 2012, and its extractive pressure has 223 been moving southward, mainly between $33^{\circ}$ and $41^{\circ} \mathrm{S}$ (SERNAPESCA, 2019). In the Chilean 224 Los Lagos Region (41 $\left.{ }^{\circ} \mathrm{S}\right)$, between 2014 and 2017 landing increased from 494 to 747 dry tons of 225 L. spicata (SERNAPESCA, 2019). This gradual increase should draw attention to kelp forest 226 conservation, since there is evidence on sustainability problems that Lessonia populations have 
227 experimented and their biodiversity in northern Chile (Vega et al., 2016). This concern acquires 228 significant relevance if we consider that the Magellan Sub-Antarctic Channels are the austral 229 distribution range of $L$. spicata, -where kelp forest populations are important for sustainability of 230 small-scale fisheries (e.g. king crab; Cárdenas et al., 2007), indigenous traditions (Ojeda et al., 231 2018) and terrestrial and marine biodiversity (Darwin, 1839; Rosenfeld et al., 2014).

232

\section{Conclusion}

Despite the geographical distance and the presence of important biogeographic breaks $\left(41^{\circ}\right.$ 235 and $46^{\circ} \mathrm{S}$ ), our results confirm that the individuals collected in the coastal zone of the Katalalixar Reserve are the species Lessonia spicata. The strong morphological and genetic evidence are indicating that the individuals analyzed are associated with the lineage of central Chile, and the populations of $L$. spicata would inhabit the area exposed to the Pacific.

With diverse industrial uses, including providing phycocolloids in the form of alginate $L$. spicata is a potentially important economic resource in the Chilean coast. However, with extractive pressure moving to the south, caution is needed given that this kelp serves not only as a habitat for many animals but also as a spawning ground for some benthic (e.g., gastropods) species.

\section{Acknowledgements}

This work was financially supported by FONDECYT 1180433 to A.M.; by Project Conicyt PIA Support CCTE AFB170008 "through the Institute of Ecology and Biodiversity (IEB)" to S.R. and A.M., and by FONDECYT 3180539 to M.S.C. The authors acknowledge the invitation to participate in the KATALALIXAR Expedition (winter 2018) supported by OCEANA Chile. We especially thank Lafayette Eaton for English revision and editing and to Alonso Vega, Blanca Figuerola and one anonymous reviewer for their helpful comments.

\section{References}

Asensi A, Reviers B. 2009. Illustrated catalogue of types of species historically assigned to Lessonia (Laminariales, Phaeophyceae) preserved at PC, including a taxonomic study of three South-American species with description of $L$. searlesiana sp. nov. and a new lectotypification of L. flavicans. Cryptogamie Algologie 30: 209-49. 
261 Ávila M, Hoffmann A, Santelices B. 1985. Interacciones de temperatura, densidad de flujo

262

263

264

265

266

267

268

269

270

271

272

273

274

275

276

277

278

279

280

281

282

283

284

285

286

287

288

289

290

291 fotónico y fotoperíodo sobre el desarrollo de etapas microscópicas de Lessonia nigrescens (Phaeophyta, Laminarilales). Revista Chilena de Historia Natural 58: 71-82.

Bell NE, Pedersen N, Newton AE. 2007. Ombronesus stuvensis, a new genus and species of the Ptychomniaceae (Bryophyta) from south west Chile. TAXON 56(3): 887-896. DOI: $10.2307 / 25065870$

Brattström H, Johanssen A. 1983. Ecological and regional zoogeography of the marine benthic fauna of Chile: Report no. 49 of the Lund University Chile Expedition 1948-49. Sarsia 68(4): 289-339.

Camus A. 2001. Biogeografía marina de Chile continental. Revista Chilena de Historia Natural 74(3): 587-617. DOI 10.4067/S0716-078X2001000300008.

Calderon MS, Boo SM. 2017. The Phyllophoraceae (Gigartinales, Rhodophyta) from Peru with descriptions of Acletoa tarazonae gen. \& sp. nov. and Gymnogongrus caespitosus sp. nov.. Phycologia 56(6): 686-696.

Cárdenas CA, Cañete JI, Mansilla A. 2007. Podding of juvenile king crabs Lithodes santolla (Molina, 1982) (Crustacea) in association with holdfasts of Macrocystis pyrifera (Linnaeus) C. Agardh, 1980. Investigaciones Marinas 35: 105-110.

Cho G, Klochkova NG, Krupnova TN, Boo SM. 2006. The reclassification of Lessonia laminarioides (Laminariales, Phaeophyceae): Pseudolessonia gen. nov. Journal of Phycology 42: 1289-1299. DOI 10.1111/j.1529-8817.2006.00280.x.

Darwin C. 1839. Voyages of the Adventure and Beagle. Vol. III. Journals and Remarks. 18321836. London: Henry Colburn.

Fraser CI, Thiel M, Spencer HG, Waters JM. 2010. Contemporary habitat discontinuity and historic glacial ice drivegenetic divergence in Chilean kelp. BMC Evolutionary Biology 10: 203. DOI 10.1186/1471-2148-10-203.

González A, Beltrán J, Hiriart-Bertrand L, Flores V, Reviers B, Correa JA, Santelices B. 2012. Identification of cryptic species in the Lessonia nigrescens complex (Phaeophyceae, Laminariales). Journal of Phycology 48(5): 1153-1165. DOI 10.1111/j.15298817.2012.01200.x.

Gorny M, Zapata-Hernández G. 2018. On the bathymetric and latitudinal distributions of Coelorinchus cf. cookianus (Gadiformes: Macrouridae): First record documented with a 
292

293

294

295

296

297

298

299

300

301

302

303

304

305

306

307

308

309

310

311

312

313

314

315

316

317

318

319

320

321

322

remotely operated vehicle (ROV) in interior waters of the Campana Archipelago in central Patagonia, Chile (48º S). Anales del Instituto de la Patagonia 46(2): 29-36. DOI /10.4067/S0718-686X2018000200029.

Guiry MD, Guiry GM. 2019. AlgaeBase. World-wide electronic publication, National University of Ireland, Galway. http://www.algaebase.org; searched on 07 Apr 2019.

Lancellotti DA, VASQUEZ JA. 1999. Biogeographycal patterns of benthic macroinvertebrates in the Southeastern Pacific littoral. Journal of Biogeography 26: 1001-1006. DOI 10.1046/j.1365-2699.1999.00344.x.

Lane CE, Mayes C, Druehl LD, Saunders GW. 2006. A multi-gene molecular investigation of the kelp (Laminariales, Phaeophyceae) supports substantial taxonomic re-organization. Journal of Phycology 42: 493-512. DOI 10.1111/j.1529-8817.2006.00253.x.

Lanfear R, Calcott B, Ho SYW, Guindon S. 2012. PartitionFinder: combined selection of partitioning schemes and substitution models for phylogenetic analyses. Molecular Biology and Evolution 29: 1695-1701. DOI 10.1093/molbev/mss020.

Mansilla A, Ávila M, Ramírez M, Rodríguez JP, Rosenfeld S, Ojeda J, Marambio J. 2013. Macroalgas marinas bentónicas del submareal somero de la ecorregión Subantártica de Magallanes, Chile. Anales del Instituto de la Patagonia 41: 49-62. DOI 10.4067/S0718686X2013000200004.

Martin P, Zuccarello GC. 2012. Molecular phylogeny and timing of radiation in Lessonia (Phaeophyceae, Laminariales). Phycological Research 60: 276-287. DOI 10.1111/j.14401835.2012.00658.x.

McCarthy C. 1998. Chromas version 1.45. School of Health Science, Griffith University, Southport, Queensland Australia. http://www.technelysium.com.au/chromas.html.

Ojeda J, Rozzi R, Rosenfeld S, Contador T, Massardo F, González-Calderón J, Mansilla A. 2018. Interacciones bioculturales del pueblo yagán con las macroalgas y moluscos: una aproximación desde la filosofía ambiental de campo. Magallania 46: 155-181. DOI $10.4067 / \mathrm{S} 0718-22442018000100155$.

Ojeda J, Marambio J, Rosenfeld S, Contador T, Rozzi R, Mansilla A. 2019. Seasonal changes of macroalgae assemblages on the rocky shores of the Cape Horn Biosphere Reserve, SubAntarctic Channels, Chile. Aquatic Botany 157:33-41. DOI.org/10.1016/j.aquabot.2019.06.001 
323 Oppliger VL, Correa JA, Engelen AH, Tellier F, Vieira V, Faugeron S, Valero M, Gomez G,

324

325

326

327

328

329

330

331

332

333

334

335

336

337

338

339

340

341

342

343

344

345

346

347

348

349

350

351

352

Destombe C. 2012. Temperature Effects on Gametophyte Life-History Traits and Geographic Distribution of Two Cryptic Kelp Species. PLoS ONE 7(6): e39289. DOI 10.1371/journal.pone.0039289.

Rambaut A, Suchard MA, Xie D, Drummond AJ. 2014. Tracer version 1.6. http://beast.bio.ed.ac.uk/Tracer.

Ronquist F, Teslenko M, Van Der Mark P, Ayres D, Darling A, Hohna S, Larget B, Liu L, Suchard MA, Huelsenbeck JP. 2012. MrBayes 3.2: efficient Bayesian phylogenetic inference and model choice across a large model space. Systematic Biology 61: 539-542. DOI 10.1093/sysbio/sys029.

Rosenfeld S, Ojeda J, Hüne M, Mansilla A, Contador T. 2014. Egg masses of the Patagonian squid Doryteuthis (Amerigo) gahi attached to giant kelp (Macrocystis pyrifera) in the subAntarctic ecoregion. Polar Research 33: 1-5. DOI 10.3402/polar.v33.21636.

Rozzi R, Massardo F, Mansilla A, Squeo FA, Barros E, Contador T, Frangopulos M, Poulin E, Rosenfeld S, Goffinet B, González-Weaver C, MacKenzie R, Crego RD, Viddi F, Naretto J, Gallardo MR, Jiménez JE, Marambio J, Pérez C, Rodríguez JP, Méndez F, Barroso O, Rendoll J, Schüttler E, Kennedy J, Convey P, Russell S, Berchez F, Sumida PYG, Rundell P, Rozzi A, Armesto J, Kalin-Arroyo M, Martinic M. 2017. Parque Marino Cabo de Hornos - Diego Ramírez. Technical report to the proposal for creation of the Cape Horn Diego Ramírez Marin Park. Punta Arenas, Chile: Ediciones Universidad de Magallanes. https://issuu.com/umag9/docs/ebook_low_parque_marino_umag_fin_di

Santelices B, Meneses I. 2000. A reassessment of the phytogeographic characterization of Temperate Pacific South America. Revista Chilena de Historia Natural 73(4): 605614. DOI 10.4067/S0716-078X2000000400005.

Santelices B, Aedo D, Hoffmann AJ. 2002. Banks of microscopic forms and survival to darkness of propagules and microscopic stages of macroalgae. Revista Chilena de Historia Natural 75: $547-555$

Santelices B, Hoffmann AJ, Aedo D, Bobadilla M, Otaíza M. 1995. The bank of microscopic forms on disturbed boulders and stones in tide pools. Marine Ecology Progress Series 129: 215-228.

Peer) reviewing PDF | (2019:06:38495:1:1:REVIEW 25 Jul 2019) 
353 Searles RB. 1978. The genus Lessonia Bory (Phaeophyta, Laminariales) in Southern Chile and

354

355

356

357

358

359

360

361

362

363

364

365

366

367

368

369

370

371

372

373

374

375

376

377

378

379

380

381

382

383

Argentina. British Phycological Journal 13: 361-381. DOI 10.1080/00071617800650421.

SERNAPESCA 2019. Informe Final Control Cuota Algas Pardas I, III, IV y VII año 2018; Huiro Negro (Lessonia berteroana/spicata), Huiro Palo (Lessonia trabeculata), Huiro Macro (Macrocystis pyrifera) y Cochayuyo (Durvillaea antarctica). Unidad de Control de Cuotas, Subdirección

De Pesquería,

Chile. http://www.sernapesca.cl/sites/default/files/informe final_2018 bentonicos algas iii_y i v.pdf

Silvestro D, Michalak I. 2012. RaxmlGUI: a graphical frontend for RAxML. Organisms Diversity and Evolution 12: 335-337. DOI 10.1007/s13127-011-0056-0.

Silva N, Rojas N, Fedele A. 2009.Water masses in the Humboldt Current System: Properties, distribution, and the nitrate deficit as a chemical water mass tracer for Equatorial Subsurface Water off Chile. Deep-Sea Research II 56: 992-1008.

Stamatakis A. 2014. RAxML Version 8: a tool for phylogenetic analysis and postanalysis of large phylogenies. Bioinformatics. DOI 10.1093/bioinformatics/btu033.

Steneck RS, Graham MH, Bourque BJ, Corbett D, Erlandson JM, Estes JA, Tegner MJ. 2002. Kelp forest ecosystems: biodiversity, stability, resilience and future. Environmental Conservation 29(4): 436-459. DOI 10.1017/S0376892902000322.

von Suhr JN. 1839. Beiträge zur Algenkunde. [N³]. Flora 22: 65-75.

Tai V, Lindstrom SC, Saunders GW. 2001. Phylogeny of the Dumontiaceae (Gigartinales, Rhodophyta) and associated families based on SSU rDNA and internal transcribed spacer sequence data. Journal of Phycology 37: 184-96. DOI 10.1046/j.15298817.2001.037001184.x.

Tamura K, Stecher G, Peterson D, Filipski A, Kumar S. 2013. MEGA6: molecular evolutionary genetics analysis version 6.0. Molecular Biology and Evolution 30: 2725-2729. DOI 10.1093/molbev/mst197.

Tellier F, Meynard AP, Correa JA, Faugeron S, Valero M. 2009. Phylogeographic analyses of the $30^{\circ} \mathrm{S}$ south-east Pacific biogeographic transition zone establish the occurrence of a sharp genetic discontinuity in the kelp Lessonia nigrescens: vicariance or parapatry. Molecular Phylogenetics and Evolution 53: 679-93. DOI 10.1016/j.ympev.2009.07.030. 
384 Tellier F, Vega JMA, Broitman BR, Vasquez JA, Valero M, Faugeron S. 2011. The importance of

385

386

387

388

389

390

391

392

393

394

395

396

397

398

399

400

401

402

403

404

405

406

407

408

409

410

411

412

413

414 having two species instead of one in kelp management: the Lessonia nigrescens species complex. Cahiers de Biologie Marine 52(4): 455-465.

Thiel M, Macaya EC, Acuña E, Arntz WE, Bastias H, Brokordt K, Camus PA, Castilla JC, Castro LR, Cortés M, Dumont CP, Escribano R, Fernández M, Gajardo JA, Gaymer CF, Gomez I, González AE, González HE, Haye PA, Illanes JE, Iriarte JL, Lancelloti DA, LunaJorquera G, Luxoro C, Manriquez PH, Marín V, Muñoz P, Navarretes SA, Perez E, Poulin E, Sellanes J, Sepúlveda HH, Stotz W, Tala F, Thomas A, Vargas CA, Vasquez JA, Vega J MA. 2007. 'The Humboldt current system of northern and centrak Chile Oceanographuic processes, ecological interactions and socioeconomic feedback', Oceanography and Marine Biology, 45, pp. 195-344.

Valdovinos C, Navarrete SA, Marquet PA. 2003. Mollusk species richness in the southeastern Pacific: why are there more species towards the pole? Ecography 26: 139-144. DOI 10.1034/j.1600-0587.2003.03349.x.

Vásquez JA, Camus PA, Ojeda FP. 1998. Diversidad, estructura y funcionamiento de ecosistemas rocosos del norte de Chile. Revista Chilena de Historia Natural 71: 479-499.

Vásquez JA, Santelices B. 1984. Comunidades de macroinvertebrados en discos adhesivos de Lessonia nigrescens Bory (Phaeophyta) en Chile central. Revista Chilena de Historia Natural 57: 131-154.

Vásquez, JA. 2008. Production, use and fate of Chilean brown seaweeds: re-sources for a sustainable fishery. Journal of Applied Phycology 20(5): 457-467. DOI 10.1007/s10811007-9308-y.

Vega JMA, Broitman BR, Vásquez JA. 2014. Monitoring the sustainability of Lessonia nigrescens (Laminariales, Phaeophyceae) in northern Chile under strong harvest pressure. Journal of Applied Phycology 26(2): 791-801. DOI 10.1007/s10811-013-0167-4.

Vega JMA. 2016. Fauna asociada a discos de adhesión del complejo Lessonia nigrescens: ¿Es un indicador de integridad ecológica en praderas explotadas de huiro negro, en el norte de Chile?. Latin American Journal of Aquatic Research 44(3): 623-637. DOI 10.3856/vol44issue3-fulltext-21.

Vega JMA, Asorey CM, Piaget N. 2016. Asociación Scurria-Lessonia, indicador de integridad ecológica en praderas explotadas de huiro negro Lessonia berteroana (ex L. nigrescens) en 

$10.4067 / \mathrm{S} 0718-19572016000200011$

417 Villouta E, Santelices B. 1984. Estructura de la comunidad submareal de Lessonia (Phaeophyta, 418 Laminariales) en Chile norte y central. Revista Chilena de Historia Natural 57: 111-122.

419 Villouta E, Santelices B. 1986. Lessonia trabeculata sp. nov. (Laminariales, Phaeophyta), a new 420 kelp from Chile. Phycologia 25: 81-86. DOI 10.2216/i0031-8884-25-1-81.1.

421

422

423

424

425 426

427

428 429

430

431

432

433

434

435

436

437

438

439

440

441

442

443

444

445

446

447

448

449

450

451

452

453

454

Westermeier R, Murúa P, Patiño J, Manoli, G, Müller DG. 2019. Evaluation of kelp harvest strategies: recovery of Lessonia berteroana (Phaeophyceae, Laminariales) in Pan de Azucar, Atacama, Chile. Journal of Applied Phycology 31: 575-585. DOI 10.1007/s10811018-1500-8.

Yoon HS, Lee JY, Boo SM, Bhattacharya D. 2001. Phylogeny of Alariaceae, Laminariaceae, and Lessoniaceae (Phaeophyceae) based on plastid-encoded RuBisCo spacer and nuclearencoded ITS sequence comparisons. Molecular Phylogenetics and Evolution 21: 231-4

Zuccarello GC, Martin P. 2016. Phylogeography of the Lessonia variegata species complex (Phaeophyceae, Laminariales) in New Zealand. Algae 31(2): 91-103. DOI 10.4490/algae.2016.31.4.15.

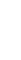

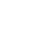

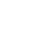

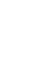

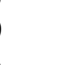

(1)




\section{Figure 1}

Collection points of Lessonia spicata. Map showing the location of Katalalixar National Reserve (KNR) in central Patagonia in the oceanic margin of the Campana Archipielago

Collection points of Lessonia spicata. a) Map showing the location of Katalalixar National Reserve (KNR) in central Patagonia, (b) Collection sites of Lessonia spicata, Torpedo Island (red circle) and Castillo Channel (blue circle) in the oceanic margin of the Campana Archipielago (KNR).
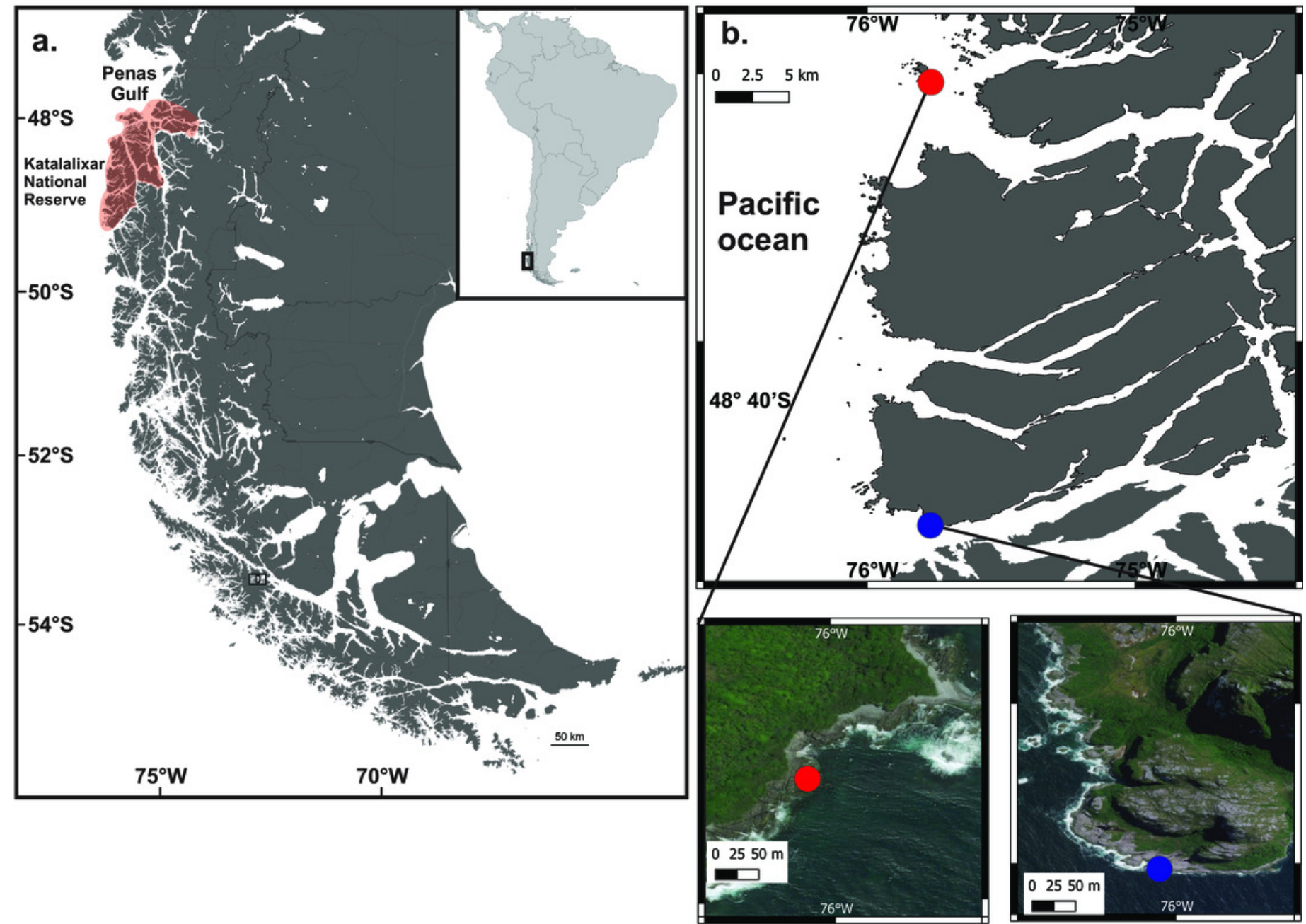


\section{Figure 2}

Distribution of Lessonia spicata (interspersed bars), showing its previously known distribution (solid bars). Habitat of specimen collected in both sites (Torpedo Island and Castillo Channel)

Distribution of Lessonia spicata (interspersed bars), showing its previously known distribution (solid bars). We included the Chilean biogeographical classification of Camus (2001). b) Habitat of specimen collected in Torpedo Island (LMS000001). c) Discoid holdfasts of specimen collected in Torpedo Island (LMS000001), d) Blades of specimen collected in Torpedo Island (LMS000001), e) Habitat of specimen collected in Castillo Channel (LMS000002, LMS000003). 


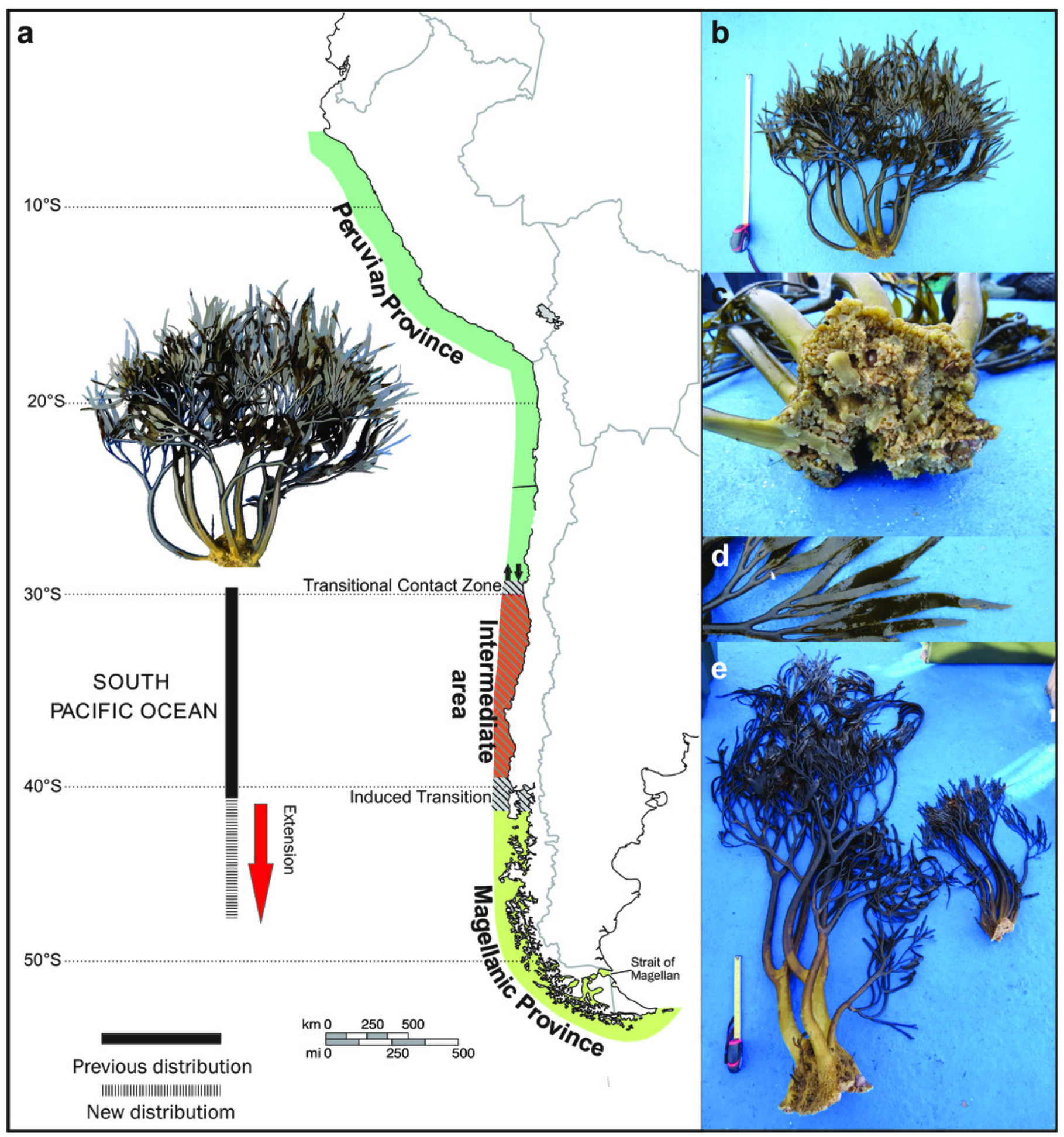


Figure 3

Cross section of the medial part of mature fronds of Lessonia species who inhabit the Sub-Antarctic channels

Cross section of the medial part of mature fronds of Lessonia spicata collected in the Katalalixar Reserve (Fig. 3a, d and g), of L. searlesiana from Fuerte Bulnes (Fig. 3b, e and h) and L. flavicans from Horn Island (Fig. 3c, f and i); mer = meristoderm, co = cortex and me = medulla, l= lacuna. 


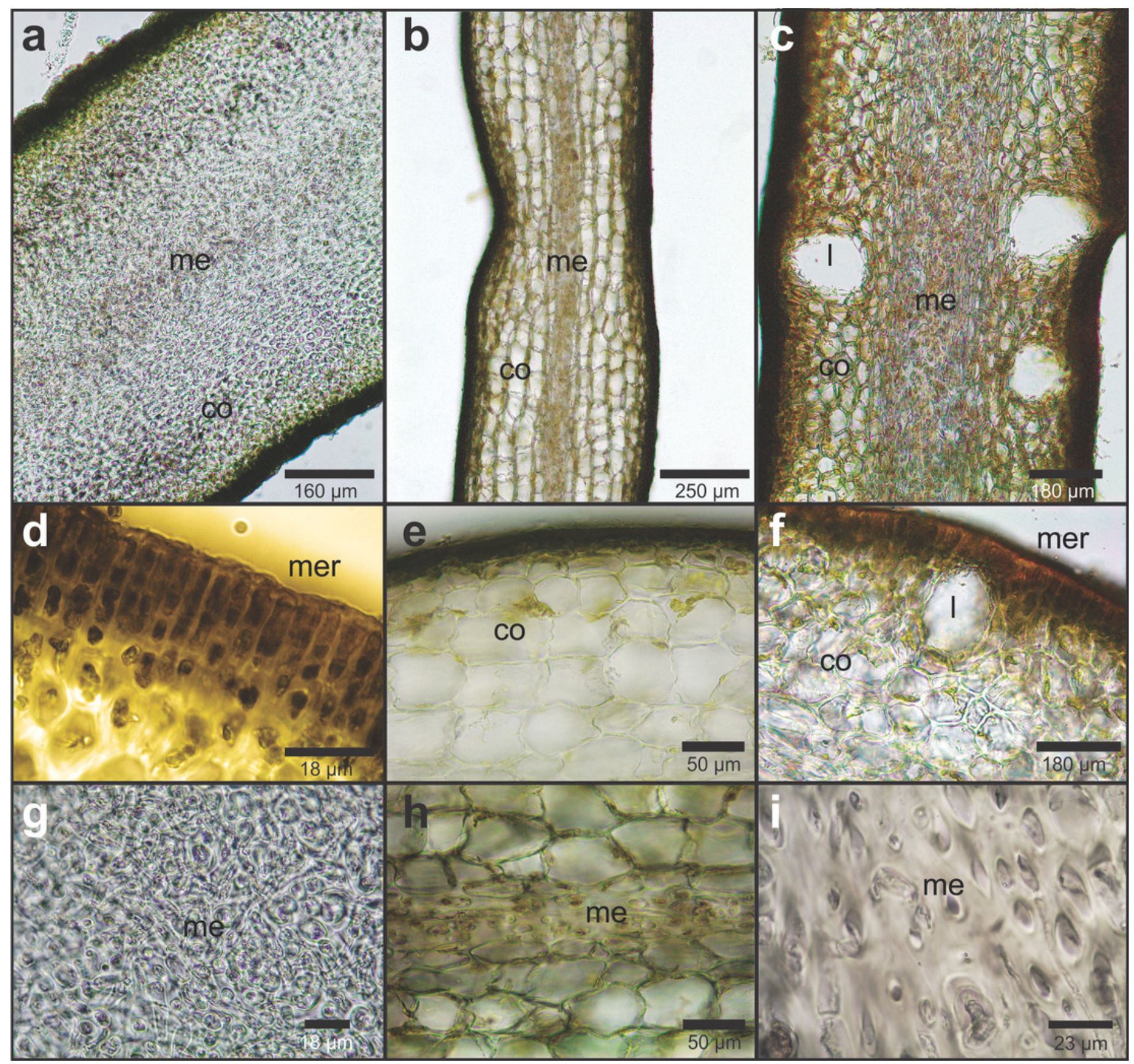




\section{Figure 4}

Phylogenetic tree of ITS sequences obtained by maximum likelihood (ML) inference.

a) Phylogenetic tree of ITS sequences obtained by maximum likelihood (ML) inference. ML bootstrap values $(\geq 50 \%)$ and Bayesian posterior probabilities $(\geq 0.90)$ are indicated next to branches. b) Cladograms of ITS sequences obtained by the neighbor joining (NJ) method. Bootstrap values ( $\geq 50 \%$ ) are indicated next to branches. The sequence for taxa in bold was generated in this study. 


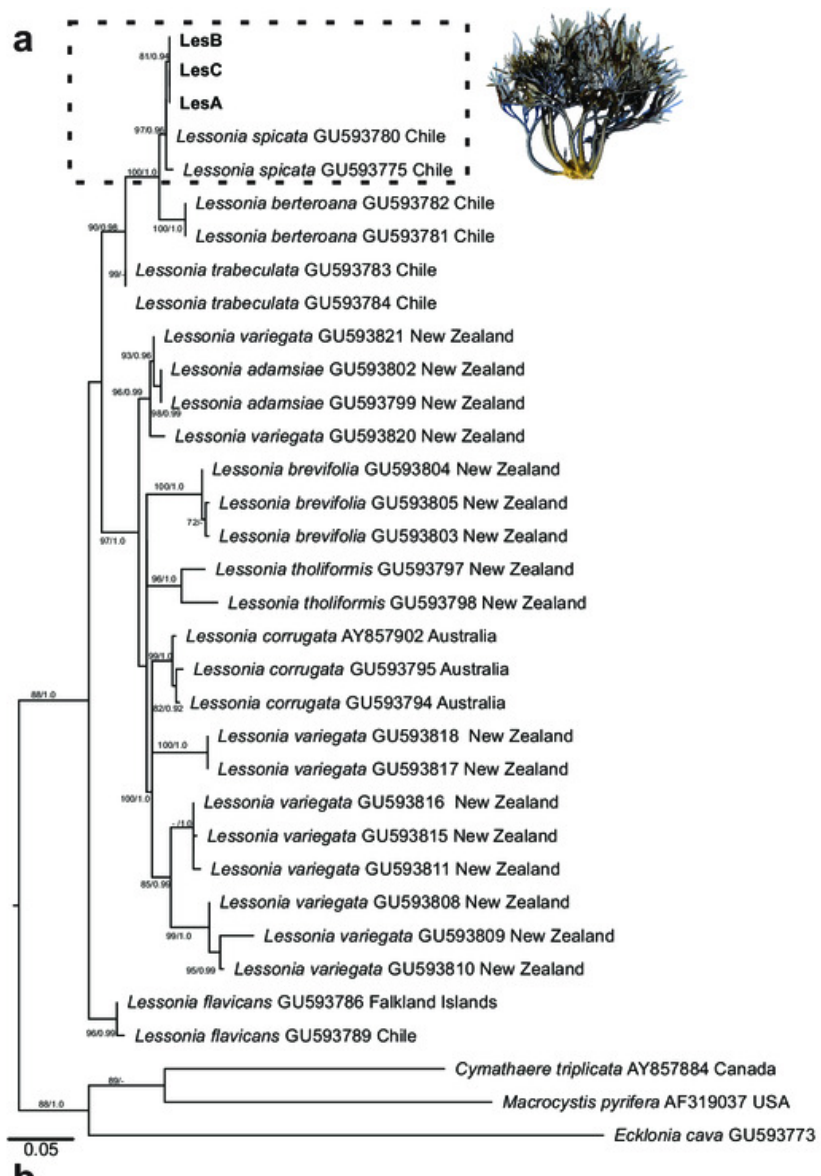

b

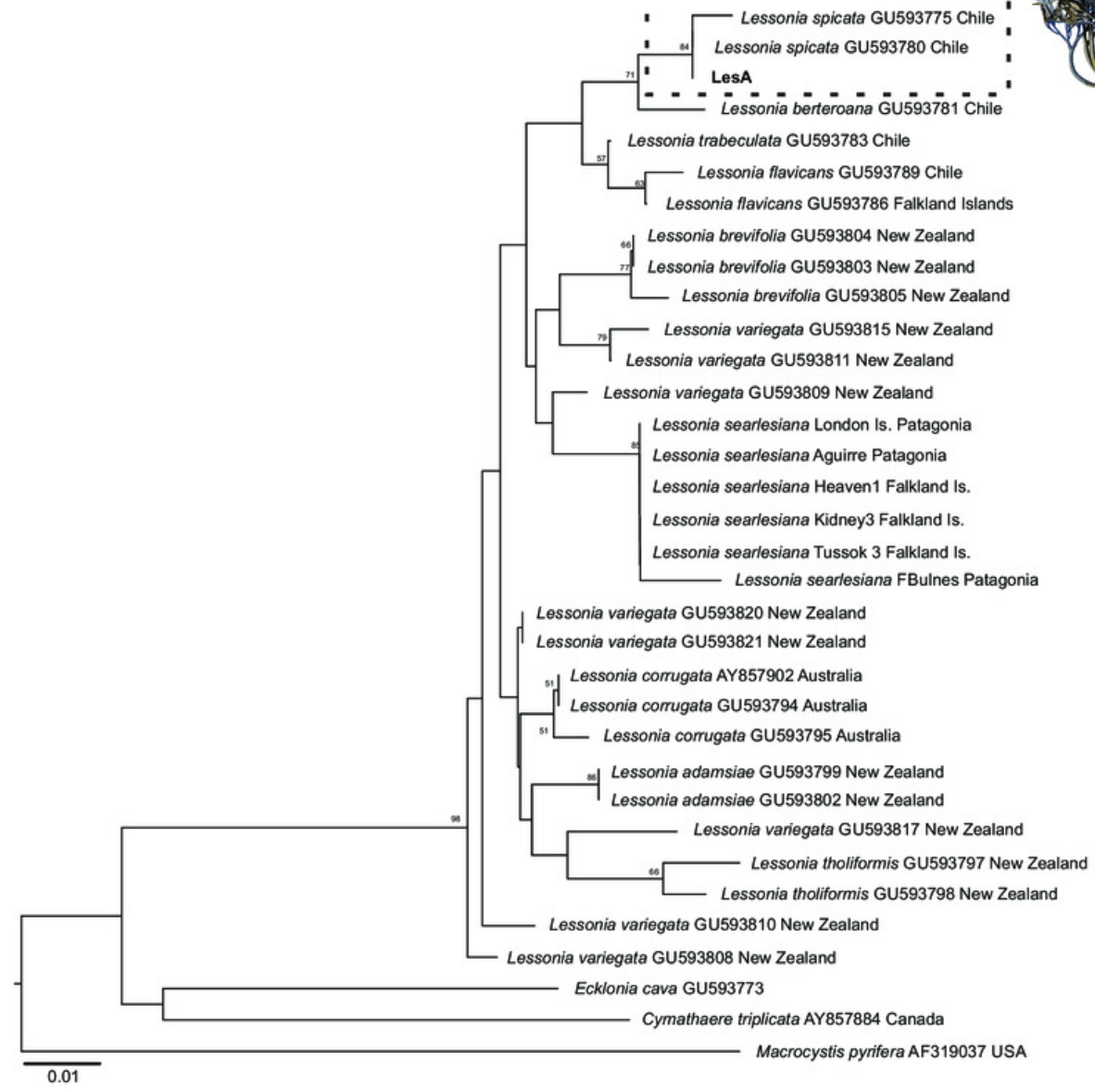




\section{Table $\mathbf{1}$ (on next page)}

List of species used in DNA analyses, information on collections and accession numbers in GenBank

List of species used in DNA analyses, information on collections and accession numbers in GenBank (sequences generated in the present study are shown in bold). ${ }^{1}$ Martin \& Zuccarello (2012), ${ }^{2}$ Lane et al. (2006), ${ }^{3}$ Yoon et al. (2001). 
1 Table 1. List of species used in DNA analyses, information on collections and accession numbers

2 in GenBank (sequences generated in the present study are shown in bold). ${ }^{1}$ Martin \& Zuccarello (2012),

$3 \quad{ }^{2}$ Lane et al. (2006), ${ }^{3}$ Yoon et al. (2001).

\begin{tabular}{|c|c|c|c|}
\hline Species & Collection site & $\begin{array}{l}\text { Voucher } \\
\text { code }\end{array}$ & ITS \\
\hline LesA & Torpedo island, Aysen, Chile & & MN061669 \\
\hline LesB & Channel Castillo, Aysen Chile & & MN061670 \\
\hline LesC & Channel Castillo, Aysen, Chile & & MN061671 \\
\hline Lessonia adamsiae & $\begin{array}{c}\text { South Promontory, The Snares, New } \\
\text { Zealand }\end{array}$ & A626 & GU593802 $^{1}$ \\
\hline Lessonia adamsiae & Tahi, The Snares, New Zealand & A614 & GU5937991 \\
\hline $\begin{array}{l}\text { Lessonia berteroana (as L. nigrescens } \\
\text { northern lineage) }\end{array}$ & San Marcos, Tarapaca, Chile & B858 & GU593781 \\
\hline $\begin{array}{l}\text { Lessonia berteroana (as L. nigrescens } \\
\text { northern lineage) }\end{array}$ & $\begin{array}{l}\text { San Marcos, Tarapaca, Chile } \\
\text { Smoothwater Bay, Campbell Is }\end{array}$ & B859 & GU593782 1 \\
\hline Lessonia brevifolia & New Zealand & A548 & GU593803 $^{1}$ \\
\hline Lessonia brevifolia & Antipodes, New Zealand & A973 & GU5938041 \\
\hline Lessonia brevifolia & $\begin{array}{c}\text { Perseverance Harbour, Campbell Is., } \\
\text { New Zealand }\end{array}$ & B296 & GU593805 \\
\hline Lessonia corrugata & $\begin{array}{c}\text { Gov. Is. Reserve, Tasmania, } \\
\text { Australia }\end{array}$ & & AY $857902^{2}$ \\
\hline Lessonia corrugata & Bicheno, Tasmania, Australia & A985 & GU593794 \\
\hline Lessonia corrugata & Skeleton Pt., Tasmania, Australia & $\mathrm{C} 057$ & GU593795 \\
\hline Lessonia flavicans & $\begin{array}{l}\text { Rookery Bay, East Falkland, } \\
\text { Falkland Islands }\end{array}$ & A634 & GU593786 ${ }^{1}$ \\
\hline Lessonia flavicans (as Lessonia vadosa) & Punta Arenas, Patagonia, Chile & B985 & GU5937891 \\
\hline $\begin{array}{l}\text { Lessonia spicata (as L. nigrescens IA } \\
\text { lineage) } \\
\text { Lessonia spicata (as L. nigrescens IA }\end{array}$ & La Pampilla, Coquimbo, Chile & A581 & GU593775 \\
\hline lineage) & Bahia Mansa, Osorno, Chile & B719 & GU593780 1 \\
\hline Lessonia tholiformis & $\begin{array}{c}\text { Wharf reef, Owenga, Chatham Is, } \\
\text { New Zealand } \\
\text { Wharekauri, Chatham Is, New }\end{array}$ & A518 & GU5937971 \\
\hline Lessonia tholiformis & Zealand & A532 & GU593798 \\
\hline Lessonia trabeculata & Punihuil, Chiloe Is, Chile & B715 & GU593783 ${ }^{1}$ \\
\hline Lessonia trabeculata & Punihuil, Chiloe Is, Chile & B716 & GU593784 \\
\hline Lessonia variegata (as $L$. variegata & North Cape, Northland, New & & \\
\hline lineage N) & $\begin{array}{c}\text { Zealand } \\
\end{array}$ & A557 & GU5938081 \\
\hline $\begin{array}{l}\text { Lessonia variegata (as L. variegata lineage } \\
\mathrm{N} \text { ) }\end{array}$ & $\begin{array}{c}\text { Maitai Bay, Northland, New } \\
\text { Zealand }\end{array}$ & B129 & GU5938091 \\
\hline $\begin{array}{l}\text { Lessonia variegata (as L. variegata lineage } \\
\text { N) }\end{array}$ & $\begin{array}{c}\text { The Sailors Grave, Coromandel, } \\
\text { New Zealand }\end{array}$ & B312 & GU593810 \\
\hline $\begin{array}{l}\text { Lessonia variegata (as } L \text {. variegata lineage } \\
\mathrm{K} \text { ) } \\
\text { Lessonia variegata (as } L \text {. variegata lineage }\end{array}$ & $\begin{array}{c}\text { South Bay, Kaikoura, New Zealand } \\
\text { New Wharf, Kaikoura, New }\end{array}$ & A138 & GU593817¹ \\
\hline K) & Zealand & A606 & GU593818 \\
\hline $\begin{array}{l}\text { Lessonia variegata (as L. variegata lineage } \\
\text { S) }\end{array}$ & Curio Bay, Catlins, New Zealand & A434 & GU5938201 \\
\hline
\end{tabular}


Lessonia variegata (as L. variegata lineage Causet Cove, Doubtful Sound, New

S)

Lessonia variegata (as L. variegata lineage

$\mathrm{W})$

Lessonia variegata (as L. variegata lineage

W)

Lessonia variegata (as $L$. variegata lineage

W)

Cymathaere triplicata

Macrocystis pyrifera

Ecklonia cava
Zealand

Princess Bay, Wellington, New

Zealand

Cape Palliser, Wairarapa, New

Zealand

Riversdale Beach, Wairarapa, New

Zealand

Whiffen Spit, Sooke, BC, Canada

California, USA
C154 GU593821 ${ }^{1}$

A001 GU593811

A613 GU593815

A025 GU593816

AY857884²

AF3190373

GU593773 ${ }^{1}$

4 


\section{Table 2 (on next page)}

Morphological measurements (mean \pm SE) of individuals collected in Torpedo Island and Castillo Channel.

External morphological data: $\mathrm{TL}=$ Thallus length $(\mathrm{cm}), \mathrm{DD}=$ Disc diameter, $\mathrm{NS}=$ Number of stipes. Internal morphological data: DC $=$ Diameter of cortical cells. 
1 Table 2. Morphological measurements (mean \pm SE) of individuals collected in Torpedo Island 2 and Castillo Channel. External morphological data: TL $=$ Thallus length $(\mathrm{cm}), \mathrm{DD}=$ Disc

3 diameter, NS = Number of stipes. Internal morphological data: DC $=$ Diameter of cortical cells.

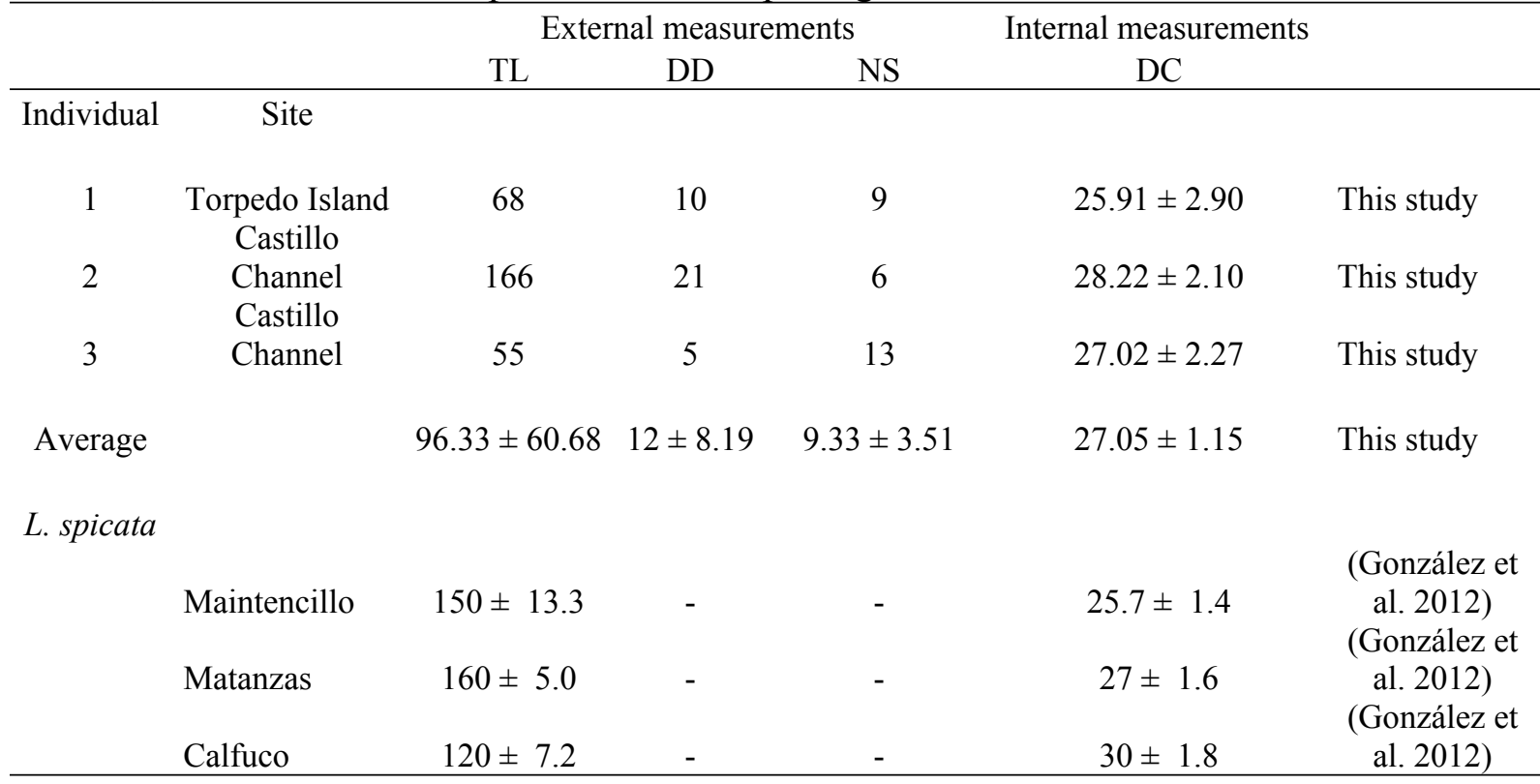

4

5 